\title{
The latitudinal uniformity of the unique life history of Velia caprai (Heteroptera: Veliidae) and notes to the pre-overwintering period of selected water striders (Heteroptera: Gerridae)
}

\section{Tomáš Ditrich, Miroslav Papáček \& Mikko Heino}

Ditrich, T., Papáček, M. \& Heino, M. 2011: The latitudinal uniformity of the unique life history of Velia caprai (Heteroptera: Veliidae) and notes to the preoverwintering period of selected water striders (Heteroptera: Gerridae). - Entomol. Fennica 22: 106-112.

Temperate water striders (Gerridae) overwinter as adults and die after spring reproduction. European water cricket Velia caprai (Veliidae) overwinters concurrently in egg and adult stage in Central Europe. This rare overwintering strategy goes with longevity of this species. Adults can survive two winters in Central Europe, unlike other semiaquatic bugs. Scandinavian populations of $V$. caprai and water striders Gerris lacustris and G. lateralis were examined at the beginning and end of September to determine their life histories. Both gerrids start to overwinter during September, females prior to males and macropterous individuals prior to brachypterous. All females of G. lacustris and G. lateralis enter reproductive diapause before winter. $V$. caprai overwinters in both adult and egg stage in Norway, and can probably survive two winters. Central European and Scandinavian populations of $V$. caprai share the same unusual way of overwintering and probably also the whole life history.

T. Ditrich, Faculty of Education, University of South Bohemia, Jeronýmova 10, 37115 České Budějovice, Czech Republic, and Faculty of Science, University of South Bohemia, Branišovská 31, 37005 České Budějovice, Czech Republic; Email: ditom@pf.jcu.cz

M. Papáček, Faculty of Education, University of South Bohemia, Jeronýmova 10,371 15 České Budějovice, Czech Republic; E-mail: papacek@pf.jcu.cz M. Heino, Department of Biology, University of Bergen, PO Box 7803, N-5020 Bergen,Norway; E-mail:mikko.heino@bio.uib.no

Received 2 September 2010, accepted 22 November 2010

\section{Introduction}

The water cricket Velia caprai caprai Tamanini, 1947 (hereafter used $V$. caprai refers to this subspecies) colonizes small forest streams and puddles in most European countries (Mielewczyk 1980, Aukema \& Rieger 1995, Ditrich et al.
2008). As other semiaquatic bugs (Heteroptera: Gerromorpha), $V$. caprai moves on a water surface and feeds on arthropods trapped into a water surface film. However, this species has a unique life history, quite different from other semiaquatic bugs. According to available data, all temperate water striders (Gerridae) and other Eu- 


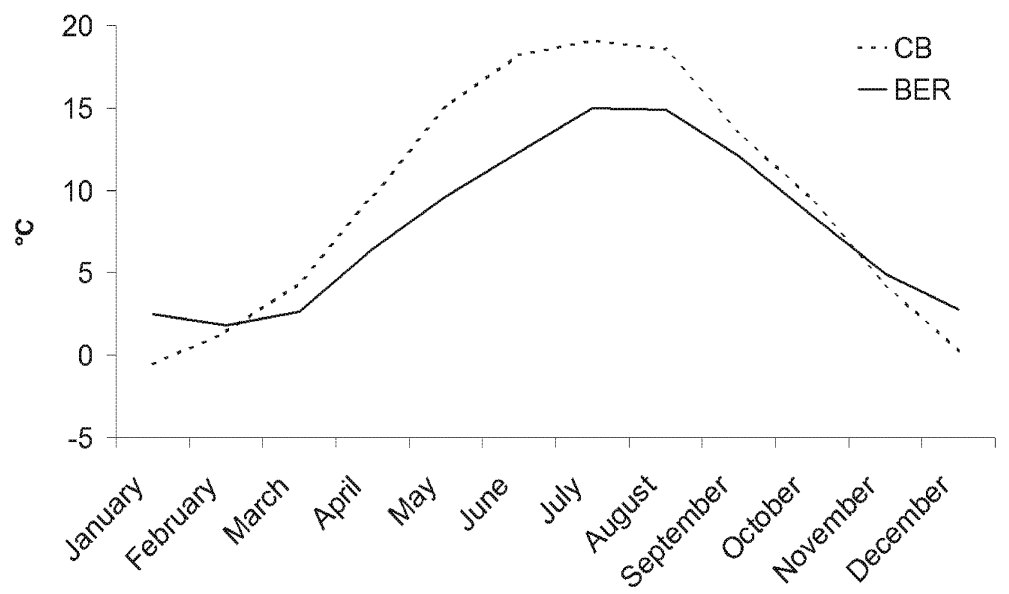

Fig. 1. Monthly means of temperature in Bergen, Norway (BER) and České Budejovice, the Czech Republic (CB) for years 2000-2008. Data were obtained from Norwegian Meteorological Institute (2009) for Bergen, Flesland (station $50500 ; 60^{\circ} 17^{\prime} 21^{\prime \prime} \mathrm{N}, 5^{\circ} 13^{\prime} 35^{\prime \prime} \mathrm{E}$ ) and The Czech Hydrometeorological Institute

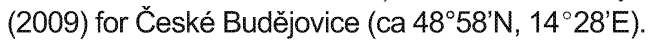

ropean semiaquatic bugs overwinter exclusively as adults (Brinkhurst 1959, Wróblewski 1980, Spence \& Andersen 1994). The pondweed bug Mesovelia furcata Mulsant \& Rey, 1852 (Mesoveliidae) is the exception, as it overwinters exclusively in the egg stage (Zimmermann 1984). The second exception is the $V$. caprai. It regularly overwinters in both egg and adult stage in the South Bohemia, the Czech Republic (from $48^{\circ}$ $37^{\prime} \mathrm{N}$ to $49^{\circ} 10^{\prime}$ ), as was recently shown by $\mathrm{Di}-$ trich \& Papáček (2009b). Moreover, adults of $V$. caprai can successfully overwinter two consecutive winters and thus exhibit extreme longevity (Ditrich \& Papáček 2009a). E.g., male adult, marked and released in October 2007 in Novohradské Hory Mts. (the Czech Republic), was recaptured alive in September 2009 (T. Ditrich, unpubl.). Single specimen can thus survive three succeeding winters - first in the egg stage and other two as adult. Such ability of an individual to survive two seasons successfully is unusual among Gerromorpha. $V$. caprai thus exhibit unique life history in conditions of Central Europe. However, the closely related $V$. saulii probably shares at least some life history traits (including overwintering strategy) with $V$. caprai (T. Ditrich \& V. Koštál, in prep.), but because knowledge on life history of this species is too scarce, we consider the life history of $V$. caprai as unique. We realize that this uniqueness results from limited knowledge on life history of some other species.

A question is whether populations of $\mathrm{V} . \mathrm{Ca}$ prai from different latitudes have equal life history strategy. Data from most surveys report this species as univoltine, hibernating as adult (Coulianos et al.2008), or partly bivoltine, hibernating as adult (Mielewczyk 1980, Wróblewski 1980, Savage 1989). Because the distribution of $V$. caprai reaches far to North, Norwegian populations were checked if the bugs share the same life history as in Central European populations. Whereas climate in the Czech Republic is typically temperate continental (relatively warm summers and cold winters), the climate in Bergen is northern oceanic (colder summers and mild winters, Fig. 1). Hypothetical uniformity of life strategy within these different regions thus would indicate that the life history is shared by all populations in Europe. For ensuring uniqueness of presumed life history, also other common semiaquatic bugs, present in the study area, were examined.

\section{Material and methods}

Populations from Bergen area $\left(60^{\circ} 15^{\prime} \mathrm{N}\right.$ to $60^{\circ}$ $25^{\prime} \mathrm{N}$ ) in Norway were chosen to compare life histories of semiaquatic bugs. All sites (see be- 


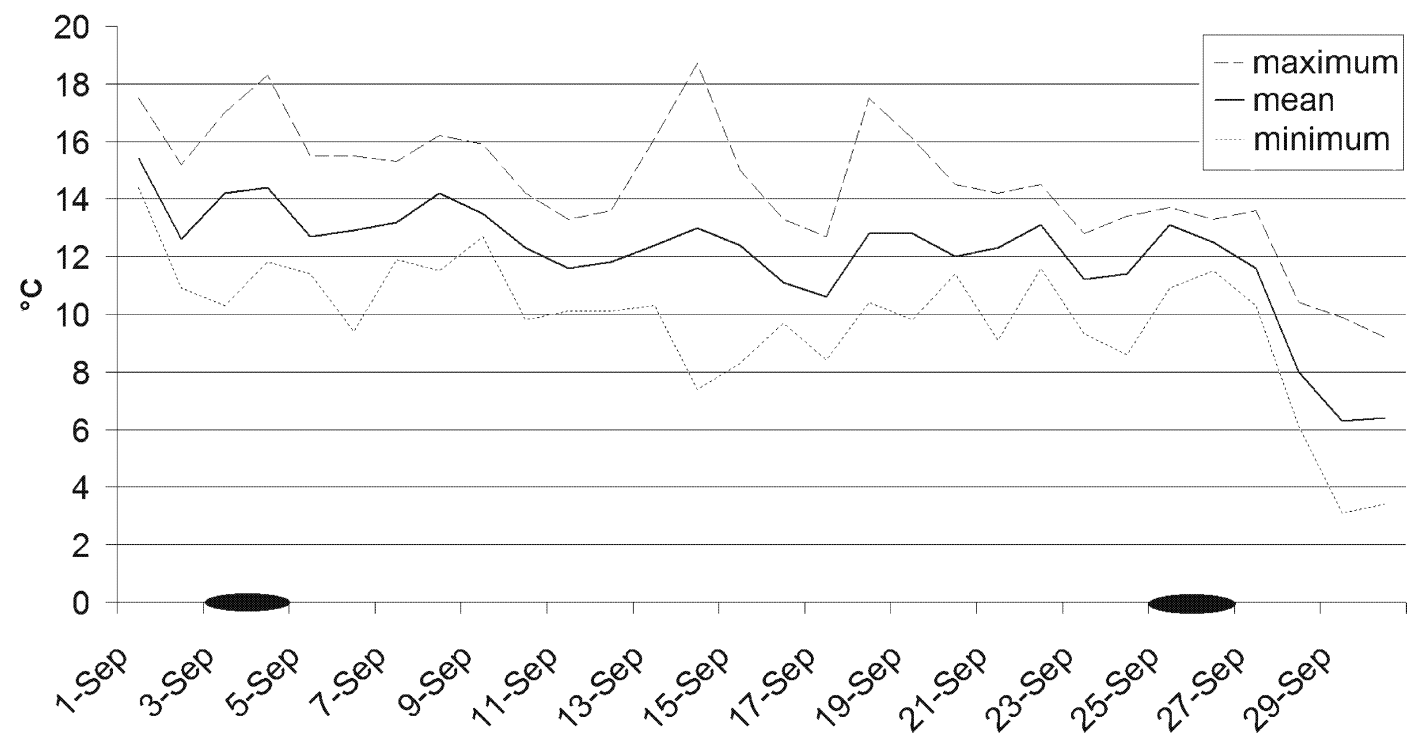

Fig 2. Mean, minima and maxima of daily temperatures in Bergen area (see Fig. 1) during September 2009. First and second collecting period is denoted with black ellipses.

low) were sampled using a hand-net $(27 \mathrm{~cm}$ diameter) by sweeping free water surface, water plants and vegetation on a shore. Several species of Gerromorpha should be abundant in this area (Coulianos et al. 2008). However, only V. caprai (Veliidae), Gerris lacustris Linnaeus, 1758 and Gerris lateralis Schummel, 1832 (Gerridae) were found in a sufficient number here. All collecting sites were sampled twice, at the beginning of September (3-5 September 2009, first period) and at the end of September (25-27 September 2009, second period), when most of the insects began to migrate to overwintering sites. Sampling was semi-quantitative, i.e., 30 minutes intensive collecting of bugs on water surface and sweeping littoral vegetation.

The temperatures between collection periods were rather regular with only slight decrease in Bergen area (Fig. 2).

\subsection{Study organisms and collecting sites}

Gerris lacustris is a common water strider, mostly found on lakes and ponds. This species is wing polymorphic, univoltine or partly bivoltine in Scandinavia (Vepsäläinen 1974, Coulianos et al. 2008). Individuals used in this study were sampled in Myravatnet Lake $\left(60^{\circ} 19^{\prime} 59.6^{\prime} \mathrm{N}\right.$, $\left.5^{\circ} 21^{\prime} 26.4^{\prime \prime} \mathrm{E}\right)$ and Bjornevatnet Lake (60 $17^{\prime}$ 16.1'N, 5²1'34.6”'E).

The water strider Gerris lateralis, common in Northern Europe, is usually found at peat bogs or small shady water bodies. It is mostly univoltine with apterous and macropterous wing morph in Scandinavia (Vepsäläinen 1974, Coulianos et al. 2008). This water strider was found abundant on peat bogs of the Stavollen-Hordness area $\left(60^{\circ} 16^{\prime}\right.$ 34.6”N, 5'18'37.4'E), where it was sampled.

The water cricket Velia caprai commonly occurs in small forest streams. Its adults are usually apterous, rarely macropterous (Brinkhurst 1959, Ditrich et al. 2008). It is supposed to be univoltine/bivoltine in Norway (Coulianos et al. 2008). Its individuals were collected in a stream in Nattland area $\left(60^{\circ} 20^{\prime} 18.6^{\prime \prime} \mathrm{N}, 5^{\circ} 22^{\prime} 13.6^{\prime \prime} \mathrm{E}\right)$ and in forest streams and puddles of the Stavollen-Hordness area (see above for the coordinates).

\subsection{Determining life history}

Specimens from all sites sampled within one date were pooled. The sex ratio, proportion of wing morphs in adults and developmental stages were recorded. Subsequently, 30 adult females were randomly picked up for a dissection. The state of 
Table 1. Counts of collected adults, their sex and wing morph. MP: macropterous, BP: brachypterous, AP: apterous. First collecting period: $3^{\text {rd }}-5^{\text {th }}$ September, second collecting period: $25^{\text {th }}-27^{\text {th }}$ September.

\begin{tabular}{|c|c|c|c|c|}
\hline \multirow[b]{2}{*}{ Gerris lacustris } & \multicolumn{2}{|c|}{ First period } & \multicolumn{2}{|c|}{ Second period } \\
\hline & $\partial$ & q & $\partial^{2}$ & q \\
\hline BP & 88 & 130 & 52 & 43 \\
\hline MP & 75 & 112 & 4 & 1 \\
\hline Gerris lateralis & d & 오 & $\pi$ & o \\
\hline $\mathrm{AP}$ & 35 & 36 & 14 & 5 \\
\hline $\mathrm{MP}$ & 5 & 2 & 2 & 0 \\
\hline Velia caprai & $\partial$ & 우 & $\partial$ & 우 \\
\hline AP & 111 & 160 & 123 & 202 \\
\hline
\end{tabular}

their ovaries was classified according to Ditrich \& Papáček (2009b): (i) immature (oocytes in germaria or oocytes and unovulated eggs present in the vitellaria), (ii) unreproductive mature (chorionated eggs ovulated, "corpora lutea" visible, oviposition not detected), (iii) reproductive mature (oviposition detected by visible "corpus luteum" located caudally (distally) from the last egg within an ovariole). The overwintering of eggs should be indicated by presence of mature females before winter.

Littoral and floating vegetation was searched for eggs during the sampling. In addition, live specimens (at least 50 bugs of each species) were transported to the South Bohemia and kept in seminatural conditions (outdoor plastic boxes with water and shore with moss and rocks) till November 2009, when the moss and rocks were searched for eggs.

\subsection{Statistical analyses}

Sex ratios were compared to the balanced proportion (1:1) using $\chi^{2}$ test in both collecting periods. All other differences in sex ratios, wing morph proportions and collecting periods were compared using $\chi^{2}$ contingency tables. Sexual maturity between periods was compared with the nonparametric Mann-Whitney test. The level of significance was set as $\alpha=0.05$. All tests were run in software package Statistica 8.0.

\section{Results}

Adults were mostly found in both collecting periods. Only 4 and 1 nymphs of $G$. lacustris, 1 and 0 nymphs of $G$. lateralis and 2 and 2 nymphs of $V$. caprai were found at the beginning and at the end of September, respectively. Thus, only adults were used for the analyses. The abundance of adults decreased significantly from the first to the second collecting period in both water striders $\left(\chi^{2}\right.$ $=184.2$, d.f. $=1, p<0.0001 ; \chi^{2}=32.8$, d.f. $=1, p<$ 0.0001 for $G$. lacustris and $G$. lateralis, respectively), but stayed unchanged in $V$. caprai $\left(\chi^{2}=\right.$ 2.01 , d.f. $=1, p=0.16$ ).

\subsection{Sex ratio}

Results of all samplings are summarized in Table 1. During the beginning of September, the sex ratio was significantly biased to females in $G$. lacustris and $V$. caprai $\left(\chi^{2}=15.4, d . f .=1, p<\right.$ $0.0001 ; \chi^{2}=8.9$, d.f. $=1, p=0.003$; respectively), whereas it was balanced in G. lateralis $\left(\chi^{2}=0.05\right.$, d.f. $=1, p=0.82)$. The situation changed at the end of September, when the sex ratio was balanced in $G$. lacustris $\left(\chi^{2}=1.4\right.$, d.f. $\left.=1, p=0.23\right)$, male biased in $G$. lateralis $\left(\chi^{2}=5.8\right.$, d.f. $=1, p=$ $0.016)$ and stayed female biased in $V$. caprai $\left(\chi^{2}=\right.$ 19.2, d.f. $=1, p<0.0001)$. The difference in the sex ratio between the samples from particular periods was significant in $G$. lacustris and $G$. lateralis (contingency tables, $\chi^{2}=8.1, d . f .=1, p=$ 0.004; $\chi^{2}=4.2$, d.f. $=1, p=0.04$; respectively), but non-significant in $V$. caprai (contingency tables, $\chi^{2}=0.6, d . f .=1, p=0.44$ ).

\subsection{Frequency of wing morphs}

Whereas both gerrids were found in two wing morphs (in $G$. lacustris macropterous and brachypterous, MP and BP hereafter, respectively; 
in G. lateralis MP and apterous, latter one AP hereafter), all individuals of $V$. caprai were apterous. Wing morph analyses were thus run for gerrids only.

The frequency of wing morphs was not sex dependent in any species in any sample from any collecting period (contingency tables, $\chi^{2}=0.003$, d.f. $=1, p=0.96 ; \chi^{2}=1.3$, d.f. $=1, p=0.26$ for $G$. lacustris and $G$. lateralis in the sample from the first period; $\chi^{2}=1.2$, d.f. $=1, p=0.27 ; \chi^{2}=0.7$, d.f. $=1, p=0.4$ for G. lacustris and $G$. lateralis in the sample from the second period). The wing morph data of the sexes were thus pooled. The wing morph frequency differed significantly between the samples from particular collecting periods in G. lacustris. Whereas the frequency MP morph almost equalled to that of BP morph during the first period, BP individuals dominated in the samples from the second period (contingency tables, $\chi^{2}=57.7$, d.f. $=1, p<0.0001$, Table 1). No such pattern was found in $G$. lateralis, where apterous specimens dominated in samples from both periods (contingency tables, $\chi^{2}=0.006, d . f$. $=1, p=0.94$, Table 1 ).

\subsection{State of ovaries and oviposition}

All examined females of $G$. lacustris and $G$. lateralis were immature in both periods. State of maturation in $V$. caprai differed from that found in both gerrids. Part of the females was reproductive in both periods. However, whereas most of females were immature in the first period, proportion of immature and unreproductive mature females equaled in the second collecting period (Table 2). The overall maturity of the examined females was significantly higher in the second period, compared to the first one (Mann-Whitney test, $U=299, p=0.03$ ).

No egg was found at any site during sampling in both periods. However, more than hundred eggs of $V$. caprai were found in the moss in the outdoor box in November 2009. No egg was found in the boxes with gerrids.

\section{Discussion}

The Norwegian populations of $G$. lacustris and $G$. lateralis went through significant changes
Table 2. Sexual maturity in females of $V$. caprai. Sample of 30 selected specimens found in Bergen area during two collecting periods in September 2009. For dates of periods, see Table 1.

\begin{tabular}{lccc}
\hline Period & Immature & \multicolumn{2}{c}{ Mature } \\
\cline { 3 - 4 } & & $\begin{array}{c}\text { Unrepro- } \\
\text { ductive }\end{array}$ & $\begin{array}{l}\text { Repro- } \\
\text { ductive }\end{array}$ \\
\hline First & 23 & 1 & 6 \\
Second & 11 & 11 & 8 \\
\hline
\end{tabular}

during September. Individuals begun to prepare for the winter and number of active specimens of both species decreased. Females started to disappear earlier/faster than males in both $G$. lacustris and $G$. lateralis. Population of $V$. caprai stayed unchanged with regard to the number of adults and the sex ratio. Both gerrids thus prepare for overwintering earlier than $V$. caprai. As there was not an apparent decrease of temperature between the collection periods, the preparation for overwintering happens probably due to the change of the photoperiod rather than change in temperature. Prolonged activity of $V$. caprai before winter is in accordance with rather active overwintering of this species (Ditrich \& Papáček 2009b). The female biased sex ratio in $V$. caprai in autumn populations is known from several European regions (Erlandsson 1993, Ditrich \& Papáček 2009b).

The population of the water strider $G$. lacustris exhibited significant change in the frequency of the wing morphs during the collecting periods in September. The macropterous individuals disappeared earlier than the brachypterous ones. This phenomenon was found also in Great Britain and Finland (Brinkhurst 1959, Vepsäläinen 1974). According to Brinkhurst (1959), long winged individuals leave water and migrate to overwintering sites earlier than the short winged ones. Later, Andersen (1973) explained this feature by the higher frequency of brachypterous individuals among adults emerged in autumn. The results in the present study tend towards the first explanation, because the wing morph frequency changed significantly in almost exclusively adult population.

All examined females of both investigated 
gerrids were immature during September, without any progress in development of ovaries when comparing samples from the first and the second collecting period. These species thus overwinter in reproductive diapause, reach sexual maturity and reproduce in spring, as commonly accepted for water striders (Spence \& Andersen 1994). The presence of reproductive females of $V$. caprai in samples from both collecting periods can be explained by either (i) rapid sexual maturation of all females of the newly hatched summer generation, (ii) differently timed sexual maturation in differently aged time splitting cohorts of one generation that is equally finished in September, or (iii) by longevity of the fully matured old overwintering generation. As adults of $V$. caprai can apparently survive two consequent winters in the Czech Republic (Ditrich \& Papáček 2009a), and there was only one unreproductive mature female present in samples from the first collecting period, the last explanation should be preferred for the Norwegian population. State of ovaries found in females of $V$. caprai in samples from both collecting periods indicates their maturation during the autumn and possible oviposition before winter. This phenomenon was confirmed by oviposition in November, detected in females from the Norwegian population reared in seminatural conditions. $V$. caprai overwinters in both adult and egg stage in Norway. The possibility of egg overwintering of $V$. caprai, suggested by Cobben (1968) and Poisson (1924), is thus confirmed in different populations. Overwintered adults in Norway can successfully survive probably also second winter, assumed from the presence of mature females at the beginning of September, which is similar to the situation from Central Europe (Papáček \& Jandová 2003).

Brinkhurst (1959) described the life history of $V$. caprai as equal to that of the gerrids, because he found only immature females in Britain (some $54^{\circ} 22^{\prime} \mathrm{N}$ ) in late summer (middle of August). However, this author did not show data from autumn. Moreover, he examined a relatively low number of individuals and mature females did not need to be present in the summer samples. Possibly but unlikely, the life history of the Britain population of $V$. caprai differs from the continental ones. The results of the present study suggest that Brinkhurst's (1959) conclusion dealing with the life history of this species in Britain should be reexamined. The overwintering strategy of $V$. $c a-$ prai in Ireland has been studied by Murray \& Giller (1991) in detail. They claimed a non-diapause overwintering, which was later confirmed in Central Europe (Ditrich \& Papáček 2009b). However, they did not record autumn or winter oviposition in their study and presumed overwintering in different stages of adulthood and late nymphal instars. Murray \& Giller (1991) also report relative longevity of $V$. caprai (male in November 1986 was recaptured in August, 1987). Nevertheless, the presence of mature females in all samples throughout year 1987 was ascribed to overlapping generations rather than to continual survival of at least some individuals. We suppose that the ability to overwinter two succeeding winters is common to $V$. caprai through Europe.

\section{Conclusion}

Water striders start overwintering during September in Bergen area in Norway. Macropterous adults of $G$. lacustris leave water surface earlier than brachypterous ones, as proposed by Brinkhurst (1959). All gerrid females are immature when entering reproductive diapause prior to overwintering. The Scandinavian population of $V$. caprai shares the life history with Central European populations - i.e., overwinters in both adult and egg stage and the adults can probably survive two winters. The overwintering strategy of this species, unknown among other semiaquatic bugs, does not show latitudinal variability.

Acknowledgements. The study was funded by the Research Council of Norway (the YGGDRASIL mobility programme No. 195759/V11) and partially by the grant of the Ministry of Education of the Czech Republic No. MSM 6007665801 .

\section{References}

Andersen, N. M. 1973: Seasonal Polymorphism and Developmental Changes in Organs of Flight and Reproduction in Bivoltine Pondskaters (Hem. Gerridae). Entomologica Scandinavica 4: 1-20.

Aukema, B. \& Rieger, C. 1995: Catalogue of the Heteroptera of the Palaearctic Region. Volume 1 : Enicocephalomorpha, Dipsocoromorpha, Nepomorpha, Ger- 
romorpha and Leptopodomorpha. - Netherlands Entomological Society, Amsterdam. 222 pp.

Brinkhurst, R. O. 1959: Alary polymorphism in the Gerroidea (Hemiptera-Heteroptera). - Journal of Animal Ecology 28: 211-230.

Cobben, R. H. 1968: Evolutionary trends in Heteroptera. Part 1: Eggs, architecture of the shell, gross embryology and eclosion. - Centre for Agricultural Publishing and Documentation, Wageningen. $475 \mathrm{pp}$.

Coulianos, C.-C., Okland, J. \& Okland, K. A. 2008: Norwegian water bugs. Distribution and ecology (Hemiptera-Heteroptera: Gerromorpha and Nepomorpha). Norwegian Journal of Entomology 55: 179-222.

Ditrich, T., Papáček, M. \& Broum, T. 2008: Spatial distribution of semiaquatic bugs (Heteroptera: Gerromorpha) and their wing morphs in a small scale of the Pohorsky Potok stream spring area (Novohradske Hory Mts.). - Silva Gabreta 14: 173-178.

Ditrich, T. \& Papáček, M. 2009a: Correlated traits for dispersal pattern: Terrestrial movement of the water cricket Velia caprai (Heteroptera: Gerromorpha: Veliidae). - European Journal of Entomology 106: 551555.

Ditrich, T. \& Papáček, M. 2009b: Effective strategy of the overwintering of semiaquatic bugs: overwintering of Velia caprai (Heteroptera: Gerromorpha: Veliidae). _ Journal of Natural History 43: 529-543.

Erlandsson, A. 1993: Sex-ratio changes in the Water Cricket (Velia Caprai) - Why do males disappear. Aquatic Insects 15: 1-10.

Mielewczyk, S. 1980: Zur Ökologie, Biologie und Morphologie von Velia saulii Tam. und V. caprai Tam. (Heteroptera, Veliidae). - Annales Zoologici (Warsaw) 35: 285-305.

Murray, A. M. \& Giller, P. S. 1991: Life-history and overwintering tactics of Velia-Caprai Tam (Hemiptera, Veliidae) in Southern Ireland. - Aquatic Insects 13: 229-243.
Norwegian Meteorological Institute 2009: eKlima portal. — [www document]. URL http://eklima.met.no. (Site visited on 20 December, 2009)

Papáček, M. \& Jandová, L. 2003: Extreme variability of life history in the water cricket Velia caprai, Tamanini 1947 (Heteroptera: Gerromorpha: Veliidae): the study under the environmental conditions of the Novohradské hory Mts. - In: Papáček, M. (ed.), Biodiversity and environmental conditions of the Novohradské hory Mountains: 149-162. University of South Bohemia and Entomological Dept. AS ČR, České Budějovice, Czech Republic. 221 pp.

Poisson, R. 1924: Contributions a l'étude des Hémiptčres aquatiques. - Bulletin biologique de la France et de la Belgique 58: 49-305.

Savage, A. A. 1989: Adults of the British aquatic Hemiptera Heteroptera: a key with ecological notes. — Freshwater Biological Association Scientific Publication, Ambleside. 173 pp.

Spence, J. R. \& Andersen, N. M. 1994: Biology of water striders - Interactions between systematics and ecology. - Annual Review of Entomology 39: 101-128.

The Czech Hydrometeorological Institute 2009 - [www document] URL http://www.chmu.cz. (Site visited on 20 December, 2009)

Vepsäläinen, K. 1974: The life cycles and wing lengths of Finnish Gerris Fabr. species (Heteroptera: Gerridae). - Acta Zoologica Fennica 141: 1-73.

Wróblewski, A. 1980: Pluskawiaki (Heteroptera). Fauna słodkowodna polski. [True Bugs (Heteroptera). Freshwater fauna of Poland]. Vol. 8. - Państwowe Wydawnictwo Naukowe, Warszawa, Poznań. 154 pp. [In Polish.]

Zimmermann, M. 1984: Population-structure, life-cycle and habitat of the Pondweed Bug Mesovelia-Furcata (Hemiptera, Mesoveliidae). — Revue Suisse de Zoologie 91: 1017-1035. 